Leon NIEŚCIOR OMI

(Warszawa, UKSW)

\title{
NIL Z ANCYRY A JAN CHRYZOSTOM O ŻYCIU MONASTYCZNYM
}

Gdy Jan Chryzostom († 407) pisał słowo zachęty w obronie życia monastycznego Adversus oppugnatores vitae monasticae, miał za sobą stosunkowo bogate doświadczenie tegoż życia: cztery lata w osadzie cenobitycznej nieopodal Antiochii (372-376), a następnie dwa lata surowszej ascezy w górskiej jaskini, zakończonej koniecznością powrotu do miasta z powodu poważnie nadwątlonego zdrowia ${ }^{1}$. Traktat napisał prawdopodobnie krótko po powrocie do Antiochii, a więc po 378 r. $^{2}$, a na pewno przed święceniami kapłańskimi w 386 roku $^{3}$. Chryzostom wszedł w środowisko mnichów syryjskich, odznaczających się ascetycznym rygoryzmem i pewną ekstrawagancją. Mnisi jednak przyciągali mieszkańców Antiochii. Na przykład zamieszkiwana przez nich góra Silpios stanowiła cel pielgrzymek Antiocheńczyków, które można było odbywać $\mathrm{z}$ miasta $\mathrm{w}$ ciągu jednego popołudnia. Ludzie przychodzili z prośbą o uzdrowienie, egzorcyzm czy duchową poradę. $Z$ drugiej strony ta forma życia wzbudzała kontrowersje. W Antiochii jedni szczycili się kontaktami z mnichami, doznaną od nich pomoca, czy wizytą w ich celach, a inni okazaną im wrogością, jak oskarżanie przed sądem czy nawet publiczną zniewagą posuwająca się do rękoczynów4. Ktoś gotów był nawet odstąpić od wiary, zgorszony surowością ich życia ${ }^{5}$. Spór ten rozgrywał się obok, czy też w kontekście konfrontacji między chrześcijaństwem a ciagle jeszcze wpływowym pogaństwem. Były mistrz Chryzostoma, pogański retor Libaniusz († 395), wypowiadał się o mnichach pogardliwie: są wrogami bogów i mieszkańca-

${ }^{1}$ Por. Palladius, De vita s. Joannis Chrysostomi 5, ed. A.M. Malingrey, SCh 341, Paris 1988, 104-115; J. Kelly, Złote usta - Jan Chryzostom - asceta, kaznodzieja, biskup, tłum. K. Krakowczyk, Bydgoszcz 2001, 41-43.

${ }^{2}$ Por. Kelly, Zlote usta, s. 45.

${ }^{3}$ Por. Introduction, w: A comparison between a king and a monk. Against the opponents of the monastic life. Two treatises by John Chrysostom, transl. with an introduction by D.G. Hunter, Lewiston 1988, 41.

${ }^{4}$ Por. Joannes Chrysostomus, Adversus oppugnatores vitae monasticae I 2, PG 47, 320-321; W. Mayer, Monasticism at Antioch and Constantinople in the late fourth century: a case of exclusivity or diversity?, w: Prayer and spirituality in the early Church, Queensland 1998, 275-288.

${ }^{5}$ Por. Joannes Chrysostomus, Adversus oppugnatores vitae monasticae I 2. 
mi grobów ${ }^{6}$. Jeszcze bardziej napastliwie atakował ich cesarz Julian Apostata (†363), pragnący wskrzesić pogańskie państwo: zarzucał mnichom zły wpływ na społeczeństwo i mizantropię przeciwną greckiej filantropii; ich tryb życia podważa wartość życia w mieście i sprzeciwia się helleńskim ideałom ${ }^{7}$.

Nie znamy daty, kiedy Nil z Ancyry († ok. 430), mnich i teolog, napisał traktat De monachorum praestantia, utrzymany w podobnym duchu apologii monastycyzmu. Jeśli swoją magnam chartam życia monastycznego - De monastica exercitatione, zredagował pod koniec życia, ok. 426/427 r., a w interesującym nas piśmie mamy do czynienia już z wyrobionym i bardzo doświadczonym pisarzem, to być może również i to dzieło stworzył pod koniec swej działalności literackiej; kilka bowiem szczegółowych wątków powtarza się w tych obydwóch pismach.

Przyjmuje się powszechnie, że Nil z Ancyry był uczniem Jana Chryzostoma. Wzmiankę o takich ich relacjach spotykamy w Chronicon Jerzego Mnicha z 866/867 roku $^{8}$. Wskazują na nie pewne związki treściowe, istniejące w pismach Nila i Chryzostoma, a nawet wyraźne zapożyczenia ucznia od mistrza, wzbudzające zainteresowanie niektórych współczesnych badaczy. Taki związek dostrzega też francuska badaczka M. Guéard, twierdząc, że Nil w De monachorum praestantia korzysta z topoi literatury monastycznej, a jego pismo kojarzy się przede wszystkim z Chryzostomowym Adversus oppugnatores vitae monasticae ${ }^{9}$.

Chryzostomowy traktat składa się z trzech ksiagg: w pierwszej, wstępnej, autor zajmuje się przede wszystkim kontrastem pomiędzy helleńskim ideałem życia obywateli tego świata a etosem życia chrześcijańskiego i obroną stylu życia mniszego jako autentycznie chrześcijańskiej drogi życia; w księdze drugiej zwraca się do pogańskich rodziców, pokazując walory chrześcijańskiego wychowania i zachęcając do posyłania swoich chłopców na edukację do mnichów; natomiast w trzeciej księdze zwraca się z podobną zachętą do chrześcijańskich rodziców. Złotousty ma więc do wyjaśnienia konkretną kwestię, będącą motywem przewodnim pisma: czy warto młodych ludzi posyłać na wychowanie do mnichów żyjących z dala od miasta? Od tych już sporów minęło już być może ponad czterdzieści lat, gdy analogiczną polemiką zajął się Nil. Teraz jednak chodziło o spór w łonie samego monastycyzmu: lepszy jest monastycyzm klasztorny, miejski, czy pustelniczy? Pismo w zasadzie ma jednorodną problematykę, która koncentruje się wokół walorów odosobnienia i wyciszenia, anachorezy i hezychii. Rzecz jasna, w takiej dyskusji argumenty musiały być znacznie subtelniejsze.

Jak widzimy, powyższe pisma pod pewnym względem nie dadzą się porównać. Chryzostom napisał swe dziełko za młodu, w wieku może trzydziestu

\footnotetext{
${ }^{6}$ Por. Libanius, Oratio 62, 9-10.

${ }^{7}$ Por. Julianus Imperator, Epistulae 89b, 288b; zob. Hunter, Introduction, s. 64.

${ }^{8}$ Por. Georgius Monachus, Chronicon IX 9.

${ }^{9}$ Por. M.G. Guerard, Nil d'Ancyre, DSp XI, Paris 1981, 348.
} 
lat, ulegając bardziej idealizmowi, wyolbrzymionemu jeszcze przez ducha retoryki. Nil tymczasem stworzył rozprawę w wieku dojrzałym, może sześćdziesięciu czy więcej lat, mając więcej doświadczenia i metodyki. Sporą rolę odgrywał też typ przeciwnika, z którym obaj się ścierali. Oponenci Chryzostoma to poganie, czy niewyrobieni chrześcijanie, nie rozumiejący w ogóle życia monastycznego. O przeciwnikach Nila trudno cokolwiek powiedzieć. W każdym razie Nil przeciwstawia sobie styl życia mnichów, którzy wiodą życie odosobnione, walczą w pojedynkę oraz praktykują wyciszenie w jaskiniach i górach, stylowi mnichów mieszkających w społeczności miejskiej i pośród ludzi ${ }^{10}$, „prowadzących życie we wspólnocie albo pośrednie, jakąkolwiek godnością by się nie odznaczali’"11. Wyraźnie zastrzega, że nie chodzi o kontrast pomiędzy praktykującymi cnotę i nie praktykującymi, ale o różnice w obrębie pierwszej kategorii ${ }^{12}$. Zreszta, pismo Nila jest mniej polemiczne niż Jana, na co wskazuje już sam tytuł: u Chryzostoma - Przeciwko zwalczajacym życie monastyczne, u Nila - O godności mnichów żyjacych $w$ odosobnieniu. U Nila motywacja odosobnionego trybu życia mnichów staje się głównym przedmiotem uwagi, u Chryzostoma występuje ona ubocznie, zdawkowo i jest podporządkowana ogólnej konfrontacji dwóch sposobów życia: pogańskiego i chrześcijańskiego.

Pomimo powyższych trudności spróbujemy zestawić zwięźle pewne wątki obydwu pism, jednak nie w całości, lecz w wybranym aspekcie, a mianowicie pod względem motywacji anachorezy i hezychii. Motywację tę podzielimy na ściśle teologiczną i, powiedzmy, antropologiczno-filozoficzną.

\section{RACJE TEOLOGICZNE}

\section{A. NIL Z ANCYRY}

1. Zbawienie. $W$ imię dobrze pojętej miłości własnej ( $\varphi \imath \lambda \alpha v \tau i ́ \alpha)$, trzeba zatroszczyć się najpierw o własne zbawienie, ,ponieważ nikt nie jest drugiemu tak samo bliski, jak każdy dla siebie samego" "13. To troska o własny stan prowadzi niektórych do monastycznego odosobnienia. Żyjąc w wyciszeniu taki człowiek zaprowadza ład moralny w sobie, staje się czujniejszy, swobodniej obcuje z Bogiem, w przeciwieństwie do tego, kto wskutek absorbujących go zajęć zewnętrznych, nigdy nie ma czasu, aby poznać swój stan, zaniepokoić się z powodu myśli albo ukrytych namiętności ${ }^{14}$.

2. Naśladowanie Mistrza. Już w Starym Przymierzu byli lewici, którzy, wolni od doczesnych zajęć i rozproszenia, służyli Bogu czystą myślą ${ }^{15}$. Mnisi

\footnotetext{
${ }^{10}$ Por. Nilus Ancyranus, De monachorum praestantia 1 i 18, PG 79, 1061 i 1081.

${ }^{11}$ Tamże 12, PG 79, 1076A.

${ }^{12}$ Por. tamże 2.

${ }^{13}$ Tamże 14, PG 79, 1077C.

${ }^{14}$ Por. tamże 15.

${ }^{15}$ Por. tamże 17.
} 
naśladują nade wszystko Jezusa, który chętnie oddalał się od tłumu i udawał się na miejsce pustynne, własnym przykładem ,pokazując pożytek wyciszenia"16. On też przedłożył postawę Marii, która w spotkaniu z Nim nie ulegała zbędnym rozproszeniom, nad postawę Marty, rozproszonej z powodu przyziemnych posług ${ }^{17}$.

3. Kontemplacja. Uwolniony od wewnętrznych rozterek człowiek nabywa dyspozycji do skupienia i medytacji ${ }^{18}$. Ma wolny czas, aby zająć się kontemplacją ${ }^{19}$. Prowadząc czujniejsze życie, staje się bardziej zdolny do tego, by podobać się $\mathrm{Bogu}^{20}$.

\section{B. JAN CHRYZOSTOM}

W swoim traktacie Chryzostom kilkakrotnie deklaruje, że nie zamierza rozprawiać o wiecznych dobrach, przynoszonych przez życie monastyczne, ale o tych osiagalnych już teraz ${ }^{21}$. W polemice z przeciwnikami życia monastycznego, którymi byli najczęściej poganie, pragnie posługiwać się bardziej argumentami z zakresu filozofii, aniżeli teologii. Dlatego też chętnie odwołuje się do greckiej filozofii i takich jej przedstawicieli, jak Sokrates, Platon czy Diogenes. Choć u Nila wyróżniliśmy powyższe przesłanki teologiczne, to jednak i w jego piśmie przesłanki antropologiczne stają się podobnie głównym przedmiotem refleksji. Być może mistrz zainspirował go do widzenia sprawy pod takim właśnie kątem.

Pod jednym co najmniej względem Chryzostom wyłamuje się z tej metodycznej dyscypliny. W obronie życia monastycznego odwołuje się do argumentacji ściśle teologicznej, mianowicie do argumentu zbawienia. W nawiązaniu do Mt 7, 14 i 20, 16 kreśli dość pesymistyczny obraz zbawienia świata: więcej jest tych, którzy zgina, aniżeli tych, którzy ocaleją ${ }^{22}$ : istnieje realna groźba potępienia. Gardzenie bliźnim, pożądanie kobiety, zawiść, gniew, mściwość, chciwość, obmowa i inne grzechy narażają na ogień gehenny, a przecież każdy z nas podlega takim winom. Mnisi są właśnie nauczycielami cnót przeciwnych tym grzechom i służą zbawieniu bliźnich ${ }^{23}$. Walczą o duszę innych, wystawiając się na niebezpieczeństwo ze strony demona, gdyż usiłują niejako wyrwać dusze z samej jego paszczy ${ }^{24}$.

Jak wyżej wskazaliśmy, Nil w swoim piśmie zaznacza priorytet troski mniszej o własne zbawienie. U Jana Chryzostoma akcenty te padają inaczej: Bóg

\footnotetext{
${ }^{16}$ Tamże 12, PG 79, 1076A.

${ }^{17}$ Por. tamże 16; Łk 10, 41.

${ }^{18}$ Por. tamże 20.

${ }^{19}$ Por. tamże 9.

${ }^{20}$ Por. tamże 15, PG 79, 1080A.

${ }^{21}$ Por. Joannes Chrysostomus, Adversus oppugnatores vitae monasticae II 4 i 6 .

${ }^{22}$ Por. tamże I 8.

${ }^{23}$ Por. tamże I 8.

${ }^{24}$ Por. tamże I 7.
} 
stworzył człowieka, aby być pożytecznym dla innych, nie tylko dla siebie ${ }^{25}$. Naturalnie, nie brakuje takich sformułowań także u Nila, ale mnich z Ancyry w De monachorum praestantia zajmuje się tą „lepszą cząstką” życia chrześcijańskiego, czyli życiem wyciszonym, hezychia, i w tym momencie podkreśla prymat własnego zbawienia. Chryzostoma cechuje zmysł duszpasterski i również w życiu monastycznym dostrzega wymiar troski o zbawienie drugich. We wcześnie napisanym dziełku De compunctione krytykuje ostentacyjną ascezę pewnego mnicha i brak u niego gotowości do duszpasterskiej służby ${ }^{26}$.

\section{RACJE ANTROPOLOGICZNE}

\section{A. NIL Z ANCYRY}

1. Poznanie samego siebie. Asceza monastyczna stanowi ,poznawczy

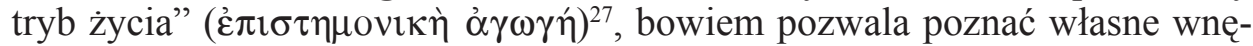
trze. Pragmatyczne rozumienie ascezy skłania Nila do zwrócenia uwagi nade wszystko na konkretne problemy, które trzeba rozwiązać. Wir rozpraszających zajęć podobny jest do wodnego potoku, który płynąc nie pozwala zobaczyć piasku na dnie; gdy zatrzyma się, piasek staje się widoczny. Na przykład przychodzące ciaggle wrażenia wzrokowe uniemożliwiają nam czystość myśli i rozpoznanie własnego stanu, bo obecne ślady zacierają poprzednie ${ }^{28}$. Ludzie żyjący w zgiełku, o ile jeszcze są w stanie uświadomić sobie popełniony grzech uczynkowy, często nie zauważają grzechu myślą̨ ${ }^{29}$. Może trawić chorego chroniczna gorączka, choć zaaferowany różnymi sprawami tego nie zauważa $^{30}$. Nieuświadomione namiętności dochodzą do głosu dopiero w stanie spoczynku człowieka: przed snem, podczas odpoczynku od pracy, w monastycznym wyciszeniu ${ }^{31}$. $Z$ koniecznym do oceny własnej sytuacji wyciszeniem wiąże się wymóg wolnego czasu $(\sigma \chi 0 \lambda \eta)^{32}$. Na refleksję nad sobą trzeba poświęcić wiele czasu.

2. Profilaktyka duchowa. Rozproszenie zewnętrzne przynosi w sposób nieunikniony duchowe szkody. Nie jest możliwe, by żyjąc w świecie nie skalać się „do jakiegoś stopnia brudami tego życia"33, nawet gdyby tego się nie uświadamiało. Zewnętrzne podniety kształtują z czasem trudne do usunięcia złe nawyki ${ }^{34}$. Doznania zmysłowe odciskają wewnątrz trwałe ślady, a wspo-

\footnotetext{
${ }^{25}$ Por. tamże III 2.

${ }^{26}$ Por. Joannes Chrysostomus, De compunctione I 6, PG 47, 402-403.

${ }^{27}$ Nilus Ancyranus, De monachorum praestantia 2, PG 79, 1064A.

${ }^{28}$ Por. tamże 4.

${ }^{29}$ Por. tamże 1.

${ }^{30}$ Por. tamże 12.

${ }^{31}$ Por. tamże 13.

${ }^{32}$ Tamże, PG 79, 1076D.

${ }^{33}$ Tamże 20, PG 79, 1085A.

${ }^{34}$ Por. tamże 19.
} 
mnienie ich przechodzi w częste o nich rozmyślanie ${ }^{35}$. Rzeczy zmysłowe dostarczają ciągle dzięki wrażeniom nowej materii dla ognia namiętności ${ }^{36}$. Dzięki odosobnieniu i wyciszeniu odcina się do pewnego stopnia materię rzeczy zmysłowych, podsycająca, „ogień natury" ${ }^{37}$, tak iż pozostaje walka z samą pożądliwością własnej natury, bez jej zewnętrznych sprzymierzeńców ${ }^{38}$. Usu-

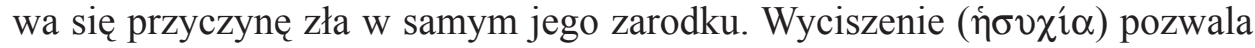
unikać kontaktu z tym, co szkodliwe, a to, co szkodliwe, nie wchodzi dzięki zmysłom do wnętrza człowieka, dzięki czemu istnieje w nim ,głęboka cisza i pokój" ${ }^{39}$. Jeśli nawet w stanie wyciszenia przychodzą jakieś naturalne wspomnienia, łatwo da się je usunąć, gdyż nie mają wielkiej siły ${ }^{40}$. Kształtujący się dobry nawyk nie pozwala na nieporządek ${ }^{41}$.

3. Metodyczna walka. W ascezie chodzi o to, by, podobnie jak w innych dziedzinach, bezpiecznie i metodycznie zdążać do celü2 . Odsunięcie się od zewnętrznych podniet i praktykowanie wyciszenia, podobne jest do strategii wojny podjazdowej, w której unika się bezpośredniej konfrontacji, a stopniowo osłabia się przeciwnika przez zasadzki i fortele ${ }^{43}$; albo też uderza się na wroga, gdy ten jest jeszcze słaby ${ }^{44}$. Innymi słowy, uderza się w zło w samym jego zarodku. Nawet więcej, w pewnym sensie praktykowanie wyciszenia jest strategią unikania walki, skoro nie jest się wystarczająco mocnym ${ }^{45}$. Samotni mnisi podobni są do wędrowców, obierających krótszą, choć trudniejszą, drogę dla uniknięcia niebezpieczeństw takich jak napaść rabusiów ${ }^{46}$.

\section{B. JAN CHRYZOSTOM}

W Chryzostomowym piśmie nie spotykamy tak dogłębnego wykładu filozoficznych argumentów za życiem monastycznym. Jednak i Antiocheńczyk sięga do racji antropologicznych, które dziś moglibyśmy nazwać psychologicznymi.

Obrazem dojrzałego mnicha pozostaje człowiek wolny od gorączki, który nie potrzebuje gasić jej żaru ciagłym sięganiem po wodę. Na przykład człowiek wolny od namiętności do kobiety, jest bardziej godny podziwu i szczęśliwszy od tego, który pożądając kobiety i żyjąc z nią, pała coraz większym pożądaniem. Nieszczęście tego drugiego polega nie tylko na tym, że jest chory

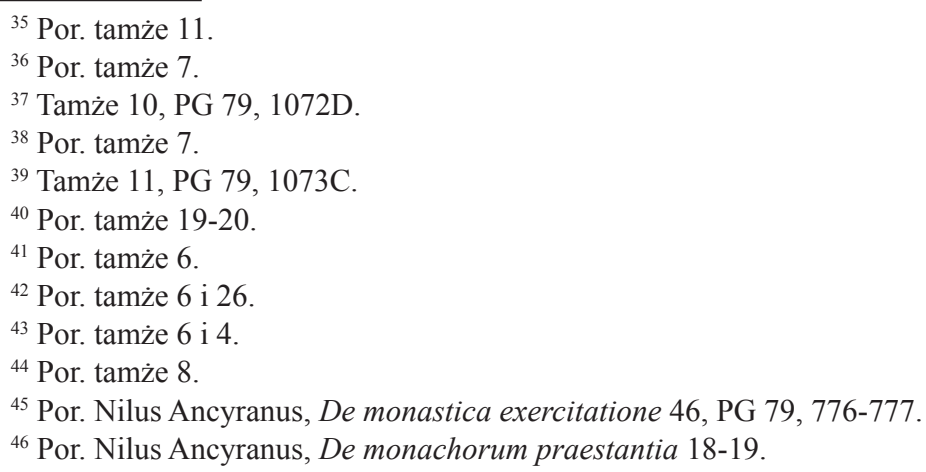


na gorączkę, ale że nie jest świadom swojej choroby i w związku z tym nie chce się z niej uwolnićt ${ }^{47}$. Tymczasem mnich, wolny od namiętności, staje ponad pokusami świata. Łatwiej mu powstrzymać się na przykład przed dążeniem do szukania własnej korzyści, przyjemności czy władzy ${ }^{48}$.

Asceza monastyczna uwalnia nie tylko od własnych namiętności, ale także od zgubnych skutków cudzych namiętności. Na przykład ubóstwo oswobadza mnicha nie tylko od chciwości, ale również od innych przykrości, jak: zawiść, kradzieże i różne zewnętrzne troski ${ }^{49}$. Nie straszna mu kradzież, zmiana miejsca przebywania czy nawet śmierć, bo prawie niczego nie $\mathrm{ma}^{50}$. Nie mając niczego, staje się właścicielem jakby wszystkiego ${ }^{51}$. Nie lęka się głodu, bo zawsze w przyrodzie znajdzie coś do zjedzenia. Nawet jest zdrowszy od ludzi żyjących w dostatku, oddychając czystym powietrzem, pijąc źródlaną wodę, czyniąc dobry użytek z roślin ${ }^{52}$. Potęga człowieka wyraża się $\mathrm{m}$. in. w tym, że jest w stanie pomścić swoją krzywdę; jednak takie położenie przewyższa stan, w którym ktoś nie może już nam wyrządzić krzywdy, choćby chciał. Mając do czynienia z człowiekiem wyzutym z wszystkiego, traci powód, by go w czymkolwiek skrzywdzićs ${ }^{53}$.

Wszystkie powyższe postawy prowadzą do głębokiego pokoju i harmonii człowieka, godzącego się z samym soba, światem i innymi ludźmi. Pada to samo słowo, co u Nila, na określenie takiego stanu, choć u Jana tylko pięć razy: $\eta \sigma v \chi i \alpha$. Człowiek gasząc w sobie niezgodną z porządkiem moralnym

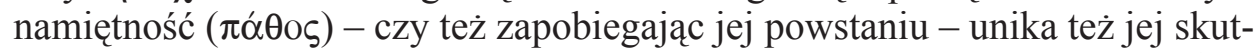
ków, a mianowicie rozterki i cierpienia, które każda namiętność przynosi ${ }^{54}$.

Mnichów można porównać do ludzi uciekających przed burzą do przystani, podczas gdy żyjący w świecie, podobni są do niesionych przez fale pośród wichru i burzy ${ }^{55}$. Mnisi doznają stanu spokoju i bezpieczeństwa ${ }^{56}$. Świat staje się im obcy, nie tylko ze względu na grożące tam namiętności, ale i dlatego, że ludzkie namiętności w efekcie stwarzają klimat korzystny dla kształtowania się struktur zła. Mnisi mają więc jeszcze jeden powód do ucieczki ze świata. Przewrócił się porządek na świecie: nieprawość panuje po miastach, a prawdziwą filozofię praktykuje się na pustyni. Nie byłoby potrzeby ucieczki na

\footnotetext{
${ }^{47}$ Por. Joannes Chrysostomus, Adversus oppugnatores vitae monasticae II 3.

${ }^{48}$ Por. tamże III 15.

${ }^{49}$ Por. tamże II 3.

${ }^{50}$ Por. tamże II 5.

${ }^{51}$ Por. tamże II 4.

${ }^{52}$ Por. tamże II 5.

${ }^{53}$ Por. tamże II 6-7.

${ }^{54}$ Fakt ten wyraża w grece sama dwuznaczność słowa $\pi \alpha ́ \theta 0 \varsigma$, które oznacza zarówno pewien afekt, jak i właśnie chorobę, cierpienie.

${ }^{55}$ Por. tamże III 15.

${ }^{56}$ Por. tamże III 11.
} 
pustynię, gdyby ład Boży panował w zamieszkałych miejscach ${ }^{57}$.

Powyższe myśli Chryzostoma najbliższe są motywowi profilaktyki duchowej, którym Nil uzasadniał monastycyzm Mnich, wyrzekając się doczesnych dóbr zdobywa wewnętrzną wolność, unika wielu rozterek i pokus. Uprzedza zło, nie dając mu możliwości zaistnienia. Chryzostom wskazując na to, że mnich wybiera drogę najbezpieczniejsza, idzie w tym kierunku, który później podejmie Nil wskazując w życiu mniszym na aspekt metodycznej walki.

$$
* * *
$$

W świetle powyższych zestawień dostrzegamy u Jana Chryzostoma i Nila z Ancyry wspólnego ducha w myśleniu o życiu monastycznym. Wspólnie odwołują się do refleksji nad naturą ludzką, która prowadzi ich obydwu do postawienia wyżej życia odosobnionego nad życiem w świecie. Z pewnościa, poza doświadczeniem monastycznym, na taki sposób patrzenia wpłynął duch współczesnej im filozofii, której świadomie ulegali. Echem pobrzmiewa ide-

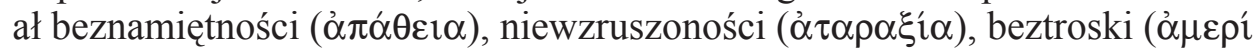
$\mu \nu \imath \alpha)$ czy inne składniki stoickiego etosu. Kilka myśli Nilowych przejawia wyraźne podobieństwo do Chryzostomowych. Wskazanie przez Nila na miejsce pobytu chwalonych mnichów - pustynia i wierzchołki gór ${ }^{58}$ - zbiega się z podobnym wskazaniem u Chryzostoma. Ale właśnie nie przypadkiem zachodzi tutaj największa zbieżność. Nil bowiem ma na myśli ten sam rodzaj monastycyzmu, co Chryzostom, gdy chce go bronić przed oponentami. W argumentacji wybiera podobny kierunek, co Chryzostom, jednak w szczegółach swoich wywodów, pozostaje niezależny. Jako uczeń Chryzostoma zapewne czytał i znał Adversus oppugnatores vitae monasticae. W De monachorum praestantia skorzystał z ducha tamtego apologetycznego utworu i niektórych jego myśli. Jednak stworzył własny i, jak się wydaje, oryginalny utwór, w zasadzie tylko ogólnie zainspirowany napisanym wcześniej przez Chryzostoma dziełkiem. Wydaje się, że to, co najbardziej spokrewnia myśl Nilową z Chryzostomowa, to ten sam duch myślenia, pewne dziedzictwo ukształtowane przez antyczną filozofię i chrześcijański ascetyzm.

Czy argumentacja starożytnych pisarzy ascezy nas przekonuje? - to już osobny rozdział. Jeśli nawet ich myśl jest uwikłana w stoicką filozofię i grecki pesymizm co do ciała, inspirowana radykalnymi prądami ówczesnego monastycyzmu, powodowana względami retorycznej przesady czy idealizacji pustelniczego monastycyzmu, to jednak pod wieloma względami pozostaje i dzisiaj „znakiem sprzeciwu” przeciwko współczesnej naiwnej ufności wobec świata i własnej natury.

\footnotetext{
${ }^{57}$ Por. tamże I 7-8.

${ }^{58}$ Por. tamże I 8; Nilus Ancyranus, De monachorum praestantia 1; Hbr 11, 37.
} 


\section{NILUS OF ANCYRA AND JOHN CHRYSOSTOM ABOUT THE MONASTIC LIFE}

\section{(Summary)}

In this article we have compared the motivations of the anachorese and hesychia in John Chrysostom's writing Adversus oppugnatores vitae monasticae and in Nilus of Ancyra writing De monachorum praestantia. We perceive there a common spirit in their thinking about the monastic life. The authors refer similarly to the contemporary reflection about the human nature, which leads them both to value the isolated life over the life in the world. It echoes the ideal of impassibility

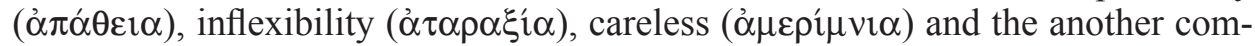
ponents of the stoic ethos. Several Nilus' reflections manifest a clear similarity to the Chrysostom's ideas. Nilus of Ancyra defends the same kind of monasticism as Chrysostom against its opponents. In his argumentation he chooses the similar direction as Chrysostom, however, he is independent in the details of his reasoning. Surely, as the Chrysostom's pupil, he read and knew Adversus oppugnatores vitae monasticae. In spite of this, he has created his own and original work, inspired only generally by the earlier Chrysostom's opuscule. 
